\title{
The Career Portfolio: A Practical Job Search Tool
}

\author{
Denise Woodbury, Southern Utah University, USA
}

Lon Addams, Weber State University, USA

William Neal, Brigham Young University - Hawaii, USA

\begin{abstract}
While resumes and interviews are a part of the typical process of obtaining a job, they are not the only tools that can be used. A career portfolio is a more complete tool. In the portfolio, the applicant includes a resume but adds evidence of abilities, knowledge, skills, and potential. These documents build credibility. A student who is graduating and seeking an entry-level position would likely include documents produced during academic coursework. Across a career, such documents would be replaced with projects completed on the job and with the permission of the employer. It can assist the individual demonstrate qualifications in a performance evaluation or for promotion. Thus, the career portfolio can be useful in obtaining an internship or entry-level position and throughout a career's progression.
\end{abstract}

Keywords: Career portfolio, performance appraisal, evidence of skills, evidence of abilities, electronic portfolio, work experience, marketing self, job search tool, interview preparation, credible documents, professional portfolio

\section{INTRODUCTION}

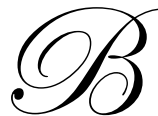

usiness communication courses are ideal for teaching practical job search tools. We typically teach college students how to write a resume and a cover letter. To assist upcoming graduates in their job search skills, some instructors do even more by providing tips for interviews and requiring mock interview practice. Is this the total package? Various professionals involved in job search research think otherwise.

In the business curricula, students are taught to communicate and to market goods and services. However, researchers believe business educators are less diligent in teaching students to market themselves. The job search research team of McCorkle, Alexander, Reardon \& Kling (2003) stressed that marketing educators have the responsibility to teach students self-marketing/job search skill development; otherwise, good students accept bad jobs, which reflects not only on the students but also on colleges and universities providing business education. Campbell (2002 and 2006), McPherson (1998), and Powell \& Jankovich (1998) also suggest that students need to be more engaged in marketing their own skills, knowledge, and abilities.

Educators in all business majors can help students market themselves by teaching their students how to build a career portfolio-with documents produced in their classes. For example, a finance instructor could require portfolio inserts, such as a survivor portfolio, investment portfolio, and a ratio analysis. Thus, the students would retain various class projects as a demonstration of skills and abilities. They might also incorporate the instructor's feedback and include a clean copy in the portfolio.

Recently, the Occupational Outlook Quarterly (2006) describes how employers are better able to determine the competency of a job seeker when provided with a collection of materials such as a resume, transcripts, letters of recommendation, and work samples. Earlier, Powell and Jankovich pointed out that the portfolio enhances the student's ability to pass the initial interview screening process. 
Moody, Stewart, and Bolt-Lee (2002) found that the portfolio demonstrates students' written communication skills, technological ability, and creativity. In a survey to representative employers (provided by the National Association of Colleges and Employers), these researchers found that 71 percent of respondents agreed that portfolios were moderately-to-extremely helpful in showcasing students' abilities. However, the respondents stressed that portfolios must be presented in an efficient, concise manner. Recruiters were interested in seeing portfolios that provided concrete examples of student achievements.

Business educators can help students self-market by creating a career portfolio, which will better prepare a business student for a successful job search and career.

Specifically, this article answers questions that arise when students prepare a career portfolio. In the remainder of this article, we answer these typical student questions by demonstrating a possible dialogue between a faculty member and a student.

\section{WHAT IS A CAREER PORTFOLIO?}

Generally, your career portfolio is a visual representation of your abilities, knowledge, and potential. The word "portfolio" is derived from the Latin words "portare" which means "to carry' and the word "folium", which means 'document' or 'artifact.' The portfolio is a collection of documents that represent events in your life-evidence of your potential through documented accomplishments. These documents build credibility. Some recruiters refer to the portfolio as a "professional portfolio."

In an article on portfolio development, Heath (2005) describes the professional portfolio as an organized collection of self-selected artifacts and self-generated reflections, developed for a specific purpose and audience, which demonstrate the writer's professional knowledge, skills, dispositions, and growth over time.

Creating a career portfolio generates both a process and a product. You communicate your accomplishments and skills to others-on paper. As you compile your portfolio, you will find yourself focusing on your values, interests, goals, and strategies, which will help in constructing a marketing package that conveys information about you.

\section{WHY SHOULD I CREATE A CAREER PORTFOLIO?}

This is a lot of work! Why should I bother to prepare a portfolio?

Compiling a portfolio is an excellent way to prepare for an interview. You should showcase your skills and abilities in the portfolio. Start documenting accomplishments and examples of your work. Store them in an organized manner, such as a portfolio binder. As you gain skills through your career, reexamine and update your portfolio.

Documents build credibility. For example, if you are a finance major, consider the vast difference in these two responses from you and another candidate applying for the same career position. The interviewer asks about your skill in capital budgeting. The other candidate says, "I am good with numbers; I have always liked working with numbers." Conversely, you, the well-prepared candidate, say, "I learned how to use a spreadsheet for budgeting on an internship three months ago; I have a copy of a budget I prepared here in my portfolio. May I show it to you?"

A further benefit of creating your portfolio is the potential realization of areas in your background that need improvement or that lack substance. Borgen, Amundson, and Reuter (2004) point out that when weak areas are identified, appropriate actions can be taken to gain needed expertise in a specific area. By finding a job announcement or internship, volunteering to help a company or agency in your community, or joining a campus club can help to acquire the skill needed. These are only a few methods students utilize to gain knowledge and specific skills. 


\section{IN WHAT SITUATION IS A CAREER PORTFOLIO VALUABLE?}

Your career portfolio will be valuable as documentation of the abilities you have developed in a variety of situations. Two common uses for your portfolio would be your (1) internship and career position interviews and (2) job performance appraisals.

\section{Internship and Career Position Interviews}

Internships provide additional expertise, outside of the classroom, in a specific area. Your career portfolio may make you more attractive as an applicant for an internship. Presenting your work to enhance your credibility makes good business sense. Your well-designed and documented career portfolio may be the edge you need to secure that prized internship.

By assembling a career portfolio, you present eye-catching evidence that enhances your "selling" process. You need to catch the interviewer's interest to increase your chance for a job offer. You can communicate your preparation, professionalism, thoroughness, and commitment through your career portfolio.

\section{Performance Appraisals}

Once the job is yours, you should continue to update your career portfolio. This way, you will have examples of your effectiveness when your supervisor reviews your performance. Your manager will appreciate documented evidence. Rather than asking the manager to recall your specific piece of work, you can say, "Here is the latest issue of our newsletter that my staff and I produced." In this situation, the manager can be reminded of your high quality work; you can let the evidence speak for itself.

For example, perhaps you designed a new web page for your department, a division, or the entire company. Instead of saying, "Ten months ago, I designed our company web page as you probably remember," you simply turn to your web page example and say, "I remember that you liked the web page I designed last spring. Here is an extra copy of the screen design."

Most employees go into a performance appraisal with fear and trepidation. Will I be able to articulate my case so that I can receive a strong evaluation? Will I get a raise? Will I be able to explain past projects so that my manager will remember my ability? How can I possibly sell myself on my past five projects in less than 15 minutes?

The answer is to "show" and briefly "remind" the manager of your value. Your portfolio will generate additional respect and reinforce his/her perception that you are a "sharp employee." Assembling high-quality written and/or visual material will impress your manager. Your boss will see the quality of your work and will be more inclined to show appreciation for your performance. This evidence may justify increased compensation or a promotion and may allow you to take on new projects.

\section{WHAT SHOULD I INCLUDE IN MY CAREER PORTFOLIO?}

Naturally, your career portfolio will be different than other career portfolios. You have different skills and experiences that you should emphasize for the particular job position you are seeking. Consider your target market, your major, and your acquired relevant skills. You will need to tailor your portfolio to emphasize your skills and abilities for a particular internship or career position. Below, the general items for all business majors are shown, followed by a list (in italics) of suggested documents produced by specific business major:

\footnotetext{
- $\quad$ Title Page ("Career Portfolio" and "Your Name")

- $\quad$ Contents Page (items/documents listed in order of appearance)

- $\quad$ Cover Letter (tailored to the job opening)

- $\quad$ Resume (tailored to the job opening)
} 
- $\quad$ Academic Plan of Study (relevant courses titles-not course numbers)

- $\quad$ Professional Goals (short term and long term)

- $\quad$ Personal mission statement

- Written and Visual Documents (e.g., a memo, case response, research report, PowerPoint presentation slides, brochure, client proposal, new product description, etc.)

- $\quad$ Evidence of Skills \& Knowledge Acquired from Academic Preparation and Work Experience ** [See specific documents for business majors below.]

- $\quad$ Leadership Experiences

- $\quad$ Community Involvement

- $\quad$ Performance Appraisals

- Awards/Certificates/Honors

- Letters of Commendation

- Other Evidence of Professionalism

- List of References

- $\quad$ Solicited Letters of Recommendation

**Common Business Majors with Personally-produced, Accompanying Documents

Accounting: (1) Systems Understanding Aid (complete accounting system for a company for two months) and (2) flow chart of an accounting system.

Business Administration: (1) a production process flow chart, (2) an evaluation of payroll benefits, (3) an analysis of a computer system potential acquisition.

Economics: (1) analysis of commercial building in a projected market area, (2) population projection for a particular city for next 20 years, (3) evaluation of a county's transportation needs for a specific timeframe.

Entrepreneurship: (1) business plan, (2) venture capital funding request, (3) pro forma financial statements.

Finance: (1) survivor portfolio, (2) risk analysis, (3) capital budgeting case, (4) ratio analysis, (5) investment portfolio, (6) leasehold evaluation.

Human Resource Management: writing a job description, (2) writing a policy statement, (3) writing a newsletter article, (4) writing a training program.

Information Systems/Technology: (1) program flow chart (2) documents showing ability to design specific systems.

Management and Business Administration: (1) a SWOT analysis for a company, (2) a strategic plan, (3) a policy statement on cell phone personal use in a firm, (4) a designed performance evaluation form.

Marketing: (1) marketing plan, (2) tri-fold brochure, (3) market research, (4) survey questionnaire instrument, (5) branding analysis, (6) new logo for a firm.

Supply Chain Management: (1) simulation report on a supply chain management $\quad$ problem, such as (a) inventory, (b) transportation, or (c) queuing, etc. (2) supplier RFP, selection, and evaluation, (3) negotiation preparation or negotiation strategy document, (4) supply chain analysis and strategy report.

Documents build credibility. Simply stating that "I have excellent written communication skills" is not convincing. Documents that show you have utilized good business writing skills is convincing. Likewise, the bullet items shown above can be powerful examples of various skills and knowledge obtained to date. 
Letters of recommendation are particularly valuable. These letters provide an objective assessment of your skills, knowledge, and work ethic by an objective source—such as a past or present manager at work or a professor at your university. When you solicit these letters, ask the writers to focus on your specific skills and attributes that will transfer to your new job.

\section{WHAT IS A GOOD FORMAT FOR MY CAREER PORTFOLIO?}

Remember that you are marketing yourself; accentuate the positive. Accordingly, invest in an attractive, leatherlook, binder. Organize your material to emphasize your abilities, education, and experience. Use sheet protectors throughout the binder to emphasize your high-quality work.

Your portfolio will be valuable throughout your career. Add or replace exhibits as you develop your skills. Tailor your portfolio to your situation. Don't send this portfolio in lieu of a resume or application. Instead, carry your portfolio with you to the interview to demonstrate your skills.

\section{WHY SHOULD I CONSIDER AN ELECTRONIC PORTFOLIO?}

For recruitment professionals, electronic portfolios are quickly becoming a popular tool in helping select candidates for interviews and for positions. A portfolio is a portable tool which you can build upon after graduation as you gain valuable work experiences.

Electronic portfolios have some advantages. According to Heath (2005), electronic portfolios are much easier to reproduce, distribute, and access. Whereas the portfolio in a binder is limited to physically handing it to interviewers in a selection process, the electronic portfolio can be duplicated quickly and easily. The use of hyperlinks allows the writer to organize the portfolio to show relationships among major headings. Supporting documents can be linked to more than one heading and to each other to indicate more complex relationships. A secondary benefit of building an electronic portfolio is the evidence itself of your technology skills, which may be quite useful to the interviewer's organization. Most importantly, though, the electronic portfolio, like the physical portfolio, helps you to market yourself.

According to Montgomery and Wiley (2008), electronic documents can be linked to each other and across standards as the writer feels appropriate. The portfolio serves as proof of the accomplishments achieved during careers.

What do you think the audience would like to see in your website? Research your options through books, web resources, trade journals, newspapers, etc. Review other career portfolio / industry websites. Consider what you like and dislike about each site. Examine the navigation, functionality, relevant material, and style.

Some of the documents that were used in the physical version of your portfolio could be included in the electronic version, including items associated with your education, work, volunteer history, awards, project samples, and reference letters. In addition, the electronic version may include screenshots, multi-media images, and audio and video clips.

Once you have created your portfolio, you may wish to store them in one of the following ways:

- $\quad$ CD - A CD is an excellent medium for publishing your final portfolio, as well as for backing up your files. They are inexpensive, have large capacity $(700 \mathrm{mb}$ ), and have long- term reliability. A CD-RW (rewritable) can be erased and re-recorded over and over, as you develop skills and abilities throughout your career.

- Web Server - Publishing your electronic portfolio to the web is the desirable option. A web site allows easy access to your portfolio by any computer with internet access, and there are no disks or CDs that can be lost. Numerous web sites can give you free storage space on their servers (accessible via the internet).

Your resume will act as the cornerstone for navigating around your website. The fundamentals of resume writing still apply; however, your career history becomes more dynamic. As you develop your electronic resume, ensure that your 
resume is:

- $\quad$ Relevant, concise, and easy to read in an electronic format.

- Gives the reader the option to print/download different versions of the resume, such as PDF, RTF, HTML, or Word.

- Has embedded links to external websites or other sections of your website. For example, if you worked at "The Asian Emporium," you may want to include www.asianemporium.com as a link on your resume.

In providing a rubric for electronic portfolios, Heath (2005) stresses the importance of each page being logically organized and readable holding to the proper use of color, type size and fonts, and contrast. Graphic files should be the appropriate format and sized to load quickly. All multimedia, including photos, graphics, video, and audio are used as artifacts to show evidence of specific skills. There should be no missing graphics, broken hyperlinks, or errors in spelling, punctuation, or grammar.

In addition to any work experience you may have, employers are interested in the technical and non-technical skills you have developed while completing your academic program. In this section of a portfolio, you could include:

- One or more project examples that are individually produced and one or more team-produced examples.

- Projects that demonstrate the multiple use of differing technical and non-technical skills.

For each project you present, you should be able to describe:

- the objectives of the project,

- $\quad$ the parameters of the project (e.g., team member responsibilities, timelines, budget considerations, resources available, etc.),

- $\quad$ the outcomes or results of the project (e.g., what you learned), and

- the business application of the project.

The most frequently visited part of your portfolio will be your work experience. The employer is looking for evidence that you are a person who understands customer service, teamwork, productivity, and efficiency.

Once an electronic portfolio has been developed, you want others to visit it. Here are some strategies that may further sell your skills:

- $\quad$ Include the web link on your resume.

- Identify your website on your cover letter.

- Mention your web link during the interview.

- Include your web link on your business card.

- Insert your web link in your follow-up and thank you letter after the interview

Throughout the interview, always look for the moment when the interviewer wants to see a document you have mentioned. It is a good idea to take a hard-copy version of the portfolio to the interview. Relying only on your electronic copy may be catastrophic if the interviewer's software or hardware is not compatible with your disk. However, be sure to leave a copy of the disk with the interviewer, in case he or she would like to review your portfolio later. Once the interviewer holds the portfolio, the likelihood is great that he / she will continue to study other pages in a well-designed and documented career portfolio.

\section{IS A CAREER PORTFOLIO WORTH ALL OF THIS WORK?}

Ryan, who graduated with a bachelor's degree eight years ago, recently found that his preparation for his "dream" job was realized: flying for a commercial airline. After graduating, he excelled in the Air Force, training pilots and logging significant flight experience. He learned that Southwest Airline would be interviewing prospective pilots. 
He was ready to transition from flying for the military to civilian flying.

Knowing the competition was keen, Ryan consulted with experts on resume writing and attended workshops on interviewing techniques. Southwest could select from thousands of applicants. All of his preparation paid off and Ryan was invited for an interview with Southwest. He carefully followed the instructions given by Southwest's recruiter. He was asked for a specific number of copies of two key documents and for numerous specific documents, such as his passport, flight documentation, test scores, etc. The recruiter gave him one week to prepare for the interview.

Since college, Ryan had been keeping a portfolio of certificates, letters of recommendation, and other documents. He easily prepared his portfolio for the interview. At the start of a group interview, the chief pilot and the pilot recruiter asked the ten candidates to hand them the previously requested number of copies of the two key documents. Ryan and another interviewee promptly handed their copies to the interview team; the other interviewees rummaged to find the documents. Some were not successful.

Ryan progressed through two more interviews with Southwest. At strategic moments, Ryan opened his portfolio to show the interviewer a document that related to the interviewer's question, even though the document had not been specifically requested by Southwest. Soon Ryan was offered a position. He learned that many of the other applicants were not hired.

This example highlights the importance of taking a well-prepared portfolio to interviews. Note that Ryan had also applied his networking, resume-writing, and interviewing skills. The career portfolio is just one of the important tools to use in a successful job search.

\section{CONCLUSION}

As professors, we help students prepare for their future careers. Now we can provide our students with one more essential tool for their toolboxes: the career portfolio. This tool may be the hammer that nails down a successful interview.

\section{SPECIAL ACKNOWLEDGMENT}

The career portfolio was an emphasis of the late Dr. Kyle Mattson throughout his career. He helped us to understand the potential impact of career portfolios for our students. We appreciate his early input on our article. Hopefully, this article is worthy of his memory.

\section{REFERENCES}

1. Borgen, W., Amundson, N. \& Reuter, J. 2004. Using portfolios to enhance career resilience. Journal of Employment Counseling, 41(2), 50-59.

2. Campbell, N. 2006. Communicating visually: incorporating document design in writing tasks. Business Communication Quarterly, 69(4), 399-403.

3. Campbell, N. 2002. Getting rid of the yawn factor: Using a portfolio assignment to motivate students in a professional writing class. Business Communication Quarterly, 65(3), 42-54.

4. Heath, M. 2005. Rubric for electronic portfolio development. Library Media Connection, 24(3), 11.

5. Heath, M. 2005. Are your ready to go digital? The pros and cons of electronic portfolio development. Library Media Connection, 23(7), 66-70.

6. McCorkle, D., Alexander, J., Reardon, J. \& Kling, N. 2003. "Developing self-marketing skills: Are marketing students prepared for the job search?”, Journal of Marketing Education, 25(3), 196-207.

7. McPherson, W. 1998. Student perception about business communication in their careers. Business Communication Quarterly, 61(2), 68-79.

8. Montgomery, Kathleen K. \& Wiley, David A. 2008. E-Portfolios, $2^{\text {nd }}$ edition, Sage Publications, Thousand Oaks, CA, 27. 
9. Moody, J., Stewart, B. \& Bolt-Lee, C. 2003. Showcasing the Skilled Business Graduate: Expanding the Tool Kit. Business Communication Quarterly, 65(4), 21-36.

10. Occupational Outlook Quarterly 2006. Career portfolios: Jobseekers show their competencies. 50(2), 26.

11. Powell, K. S., \& Jankovich, J. L. 1998. Student portfolio: A tool to enhance the traditional job search.

Business Communication Quarterly, 61(4), 72-82.

\section{NOTES}

